\title{
Historical and social construction of the practices of auxiliary nurses and nurse technicians in Primary Care
}

\author{
Construção histórica e social das práticas de auxiliares e técnicas de enfermagem na Atenção Primária \\ Construcción histórica y social de las prácticas auxiliares y técnicas de enfermería en Atención Primaria
}

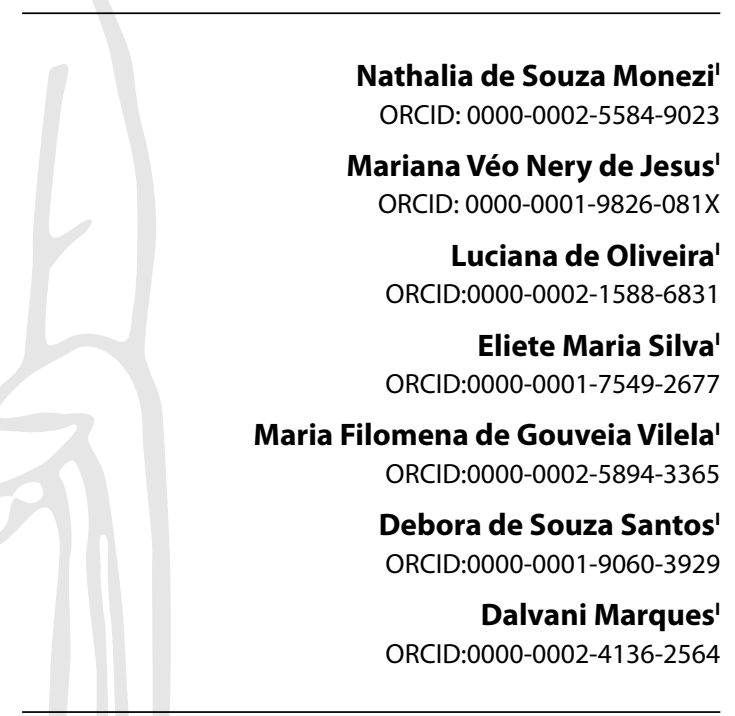

'Universidade Estadual de Campinas. Campinas, São Paulo, Brazil.

How to cite this article:

Monezi NS, Jesus MVN, Oliveira L, Silva EM, Vilela MFG, Santos DS, et al. Historical and social construction of the practices of auxiliary nurses and nurse technicians in Primary Care. Rev Bras Enferm. 2021;74(2):e20201012. https://doi.org/10.1590/0034-7167-2020-1012

Corresponding author:

Nathalia de Souza Monezi

E-mail: nathaliamonezi@hotmail.com

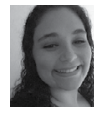

EDITOR IN CHIEF: Antonio José de Almeida Filho ASSOCIATE EDITOR: Alexandre Balsanelli

Submission: $08-30-2020$

Approval: 12-07-2020

\section{ABSTRACT}

Objectives: to analyze the practices of nursing auxiliaries and technicians in the context of Primary Health Care in a city in the interior of the state of São Paulo. Methods: transversal, quantitative study, realized with 104 nursing auxiliaries and 46 nursing technicians acting in the Primary Attention. The data, collected using structured questionnaires, are presented by descriptive statistics, and analyzed based on the essential elements of First Contact and Longitudinality. Results: the professionals were, majority, women, married, with children, low political and collective participation. We identified thirteen activities related to the First Contact: and ten on Longitudinality. Conclusions: the insertion and capillarization of auxiliary and nursing technicians' practices show these professionals as the main ones responsible for the first contact in this context, highlighting their relevance in the longitudinality of care and the work composition of health teams, contributing to the consolidation of the Unified Health System (SUS).

Descriptors: The Role of the Professional Nurse; Auxiliary Nurses; Nurse Technicians; Family Health Strategy; Primary Health Care.

\section{RESUMO}

Objetivos: analisar as práticas das auxiliares e técnicas de enfermagem no contexto da Atenção Primária em Saúde em município do interior do estado de São Paulo. Métodos: estudo transversal, quantitativo, realizado com 104 auxiliares de enfermagem e 46 técnicas de enfermagem atuantes na Atenção Primária. Os dados, coletados por meio de questionários estruturados, são apresentados por estatística descritiva e analisados com base nos elementos essenciais de Primeiro contato e Longitudinalidade. Resultados: as profissionais eram, majoritariamente, mulheres, casadas, com filhos, baixa participação política e coletiva. Foram identificadas 13 atividades relacionadas ao Primeiro contato; e 10, sobre a Longitudinalidade. Conclusões: a inserção e a capilarização das práticas das auxiliares e técnicas de enfermagem evidenciam essas profissionais como principais responsáveis pelo primeiro contato nesse contexto, destacando sua relevância na longitudinalidade do cuidado e na composição do trabalho das equipes de saúde, contribuindo para a consolidação do Sistema Único de Saúde. Descritores: Papel do Profissional de Enfermagem; Auxiliares de Enfermagem; Técnicos de Enfermagem; Estratégia Saúde da Família; Atenção Primária à Saúde.

\section{RESUMEN}

Objetivos: analizar las prácticas de las auxiliares y técnicas de enfermería en el contexto de Atención Primaria de Salud en un municipio de São Paulo. Métodos: estudio transversal, cuantitativo, realizado con 104 auxiliares de enfermería y 46 técnicas de enfermería actuantes en Atención Primaria. Los datos, recogidos por medio de encuestas estructuradas, presentados por estadística descriptiva y analizados basado en elementos esenciales de Primer contacto y Longitudinalidad. Resultados: las profesionales eran, mayoritariamente, mujeres, casadas, con hijos, baja participación política y colectiva. Identificadas 13 actividades relacionadas al Primer contacto; y 10, sobre la Longitudinalidad. Conclusiones: la inserción y la capilarización de las prácticas de las auxiliares y técnicas de enfermería evidencian esas profesionales como principales responsables por el primer contacto en ese contexto, destacando su relevancia en la longitudinalidad del cuidado y en la composición del trabajo de los equipos de salud, contribuyendo para la consolidación del Sistema Único de Salud.

Descriptores: Papel del Profesional de Enfermería; Auxiliares de Enfermería; Técnicos de Enfermería; Estrategia Salud de la Familia; Atención Primaria de Salud. 


\section{INTRODUCTION}

Primary Health Care (PHC) is the strategy proposed for reordering the Brazilian model of care, according to the principles of the SUS. It prioritizes the Family Health Strategy (FHS) to redirect individual and collective actions towards health promotion, protection, and recovery, with emphasis on integral care. The multi-professional FHS teams act positively in the determinants and conditioning of community health, with the power to transform the health situation and autonomy of people ${ }^{(1)}$.

These professionals work to create bonds, humanize management and assistance, care with responsibility, and promote citizenship towards the individual and the community. In this way, the complexity of the work object in PHC stands out: individuals, families, and communities understood as social subjects, immersed in a given territory, with specificities and social, political, economic, cultural, and symbolic singularities ${ }^{(2)}$.

The reorientation of FHS teams' work process includes activities aimed at longitudinal, planned, and programmed care based on situational diagnosis, with intersectoral actions and construction of spaces for the development of citizenship ${ }^{(1,3)}$. On a daily basis, material and relational technologies are employed in the production of health to operate in a logic that reorganizes and innovates practices towards integrality ${ }^{(4)}$.

Brazilian nursing has experienced differentiated care practices, approaching the complexity of health care in these services, emphasizing interdisciplinarity ${ }^{(5)}$. The nursing team, composed of nurses, nursing auxiliaries, and nursing technicians, is inserted in this context and fulfills a fundamental role as the leading workforce of the SUS.

Auxiliary nurses and nurse technicians constitute a significant contingent of health services workers (currently, there are 1,764,356)

${ }^{(6)}$. However, little is investigated about their practices and their role in consolidating the SUS and PHC. In this perspective, the essential elements - also known as attributes - of "First contact" with the health care network and "Longitudinality" were elected for this research ${ }^{(7)}$.

In this way, this research contributes to the recognition of auxiliary practices and nursing technicians in order to enable discussion and innovations in the nursing area in such context.

\section{OBJECTIVES}

To analyze the practices of auxiliary nurses and nurse technicians in the context of Primary Care in a municipality of the state of São Paulo.

\section{METHODS}

\section{Ethical Aspects}

The data presented in this study make up the research on the practices conducted by Nursing in the PHC, approved by the Research Ethics Committee of UNICAMP, in compliance with Resolution 466/12 of the National Health Council.

\section{Design of study}

A transversal, quantitative study, carried out in the first semester of 2017, in Health Basic Units, denominated Health Care Centers
(HCC), in Campinas, São Paulo. The PHC network was composed of $64 \mathrm{HCCs}$, to attend approximately 1.2 million inhabitants ${ }^{(8)}$. In each HCC, there were from one to five Nursing Services (NS) teams, and each one was composed of more than one auxiliary nurse or nurse technician. The study was guided by the criteria defined for observational studies (STROBE).

\section{Population and sample}

The sample size was estimated considering the methodology of sample calculation for estimation of a proportion. It was assumed a proportion equal to 0.50 , a population composed of 870 professionals, and a level of significance and sampling error equal to $5 \%$. The calculation resulted in a minimum sample of 267 professionals.

However, faced with structural and conjuncture issues and problems faced in the municipality, such as the dengue epidemic, yellow fever vaccination campaign, employees' dismissals, and retirements in these categories, access to participants was reduced, resulting in a final sample of 150 professionals: 104 auxiliary nurses and 46 nurse technicians. The study included the participants working in the HCCs for more than six months and excluded those on vacation or leave at the time of data collection.

\section{Study protocol}

For data collection, interviews were conducted through a structured questionnaire, validated by nurses who worked in the PHC. The questionnaire addressed six areas: the social profile, professional formation, social participation, professional updating, insertion in the labor market, and activities developed in the daily life of the HCCs. Regarding the activities, 51 activities were approached regarding frequency within a 30-day retrospective period: daily, weekly, fortnightly, monthly, or never.

The interviews were conducted in the HCCs, chosen at random by drawing. All the nursing professionals were invited to participate in the research; and, when there were no more local professionals, a new unit was contacted until the final sample was completed and the schedules and days were previously scheduled with the local management. To fill out the questionnaire, which lasted an average of 15 minutes, it was used the QuickTap Survey' software and printed questionnaires. The data were saved and stored in a Microsoft Excel ${ }^{\circ}$ spreadsheet.

\section{Data analysis and statistics}

The database was analyzed employing descriptive statistics, being calculated frequencies and percentages for the categorical variables ${ }^{(9)}$.

In the analysis of the activities, two of the essential attributes of PHC defined by Starfield ${ }^{(7)}$, "First contact" and "Longitudinality", were used as a basis. Based on them, a minimum of $40 \%$ was established in the frequencies of activities regarding occurrences "daily" and "eventually" (weekly, fortnightly, and monthly) for the classification of the 51 activities. Some activities were classified as "Other" because they focused on the service and work organization in the PHC. 


\section{RESULTS}

Nursing professionals' social profile identified 104 auxiliary nurses and 46 nurse technicians, being 132 (88.59\%) women and $17(11.41 \%)$ men. Regarding the marital status, 84 (56\%) were married; 26 (17.33\%), single; 23 (15.33\%), divorced; 12 (8\%), in stable union; and 5 (8\%); widows. Among them, 117 (78\%) had children. The average age was 44.97 years, varying from 23 to 69 years. However, the average was 48.39 years among the auxiliary nurses and 37.80 years among the nurse technicians.

As for professional training, 35 (23.49\%) had completed higher education, most of them with a nursing degree. Of these, 86 (57.33\%) had nursing technician training and acted as auxiliary nurses.

About social participation, none of these professionals were members of the Brazilian Nursing Association (ABEN), 46 (30.67\%) were registered with the professional union, and 13 (8.67\%) participated at the Local Health Council.

Regarding professional updating, 116 (77.33\%) reported participating in events promoted by their institution, such as training courses, updating courses, lectures, and training. Summing the two categories, 97 (64.67\%) considered themselves updated and used Internet research, books, manuals, and articles as educational tools.

About the insertion in the labor market, 132 (88\%) professionals had previous experiences: the auxiliary nurses had already worked in hospitals (86.5\%), in PHC (11.63\%), and other places such as laboratories and technician courses $(2.32 \%)$, while the nurse technicians had worked in hospitals (81.82\%) and PHC (18.18\%). In the total of the two categories, $127(84.27 \%)$ referred to a single job currently $(80.58 \%$ of the auxiliary nurses and $93.48 \%$ of the nurse technicians) - we point out that all the professionals are concurred, working in a system managed by the government.

It is worth mentioning that all nurse technicians have been working in PHC for less than ten years since the first public tender for the category only occurred in 2011. Among the auxiliary nurses, $62(60.18 \%)$ have been working for over ten years in this context (Table 1).

Regarding the categorization, as for the essential attributes "First contact" and "Longitudinality," 23 activities were grouped. The inclusion of four activities is classified as "Other," as they are focused on the service and work organization in the PHC, as presented in Table 2.

The performance of the auxiliary nurses and nurse technicians are identified in activities predominantly classified as "First Contact," highlighting some as specific in the FHS in the last years, such as the "Intake."

According to Table 2, there was a variation between frequencies of the activities "Nursing Entry" and "Production Record".

\section{DISCUSSION}

Historically, care practices have been associated with the female gender, and, socially, this profile was attributed to nursing. The professionals participating in this study were mostly women, married and with children, corroborated by the sociodemographic profile of the nursing categories ${ }^{(10)}$.
Table 1 - Time in the current job of auxiliary nurses and nurse technicians, Campinas, São Paulo, Brazil, 2018

\begin{tabular}{lcccc}
\hline Time on the job & Auxiliaries (n) & \% & Technicians (n) & $\%$ \\
\hline 1 to 5 years & 27 & 26.21 & 40 & 86.96 \\
6 to 10 years & 14 & 13.59 & 6 & 13.04 \\
11 to 15 years & 15 & 14.56 & 0 & 0 \\
16 to 20 years & 27 & 26.21 & 0 & 0 \\
21 to 25 years & 16 & 15.53 & 0 & 0 \\
26 to 30 years & 3 & 2.91 & 0 & 0 \\
More than 30 years & 1 & 0.97 & 0 & 0 \\
\hline
\end{tabular}

Table 2 - Activities performed by auxiliary nurses and nurse technicians, according to the essential attributes "First contact" and "Longitudinality" in Primary Health Care, Campinas, São Paulo, Brazil, 2020

\begin{tabular}{|c|c|c|c|c|}
\hline \multirow{2}{*}{ 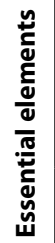 } & \multirow[t]{2}{*}{ Frequency } & \multirow{2}{*}{$\stackrel{\grave{d}}{\grave{z}}$} & \multirow{2}{*}{ 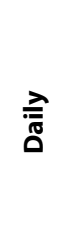 } & \multirow{2}{*}{ 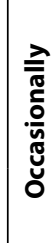 } \\
\hline & & & & \\
\hline \multirow{13}{*}{ 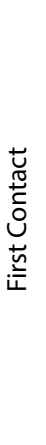 } & Intake & 7.3 & 74.6 & 18 \\
\hline & Oral drug administration & 8.72 & 49.6 & 41.5 \\
\hline & IV, IM, SL, SC, ID drug administration & 8.0 & 52.6 & 39.2 \\
\hline & Organization of patient flow inside the unit & 12.6 & 70.0 & 17.2 \\
\hline & Orientations to users & 2.0 & 95.3 & 2.6 \\
\hline & Public orientation for collection of exams & 8.0 & 70.0 & 23.9 \\
\hline & Performing pregnancy test & 22.6 & 42.0 & 35.2 \\
\hline & Emergency and Urgent Assistance Service & 29.3 & 14.6 & 55.8 \\
\hline & Electrocardiogram & 20.6 & 20.0 & 59.2 \\
\hline & Inhalation & 12.6 & 41.3 & 45.9 \\
\hline & Notification of compulsory diseases (SINAN) & 42.2 & 11.4 & 46.2 \\
\hline & $\begin{array}{l}\text { Filling out compulsory notification disease forms } \\
\text { (SINAN) }\end{array}$ & 31.5 & 12.0 & 56.2 \\
\hline & Verification of anthropometric data & 34.6 & 18.0 & 47.2 \\
\hline \multirow{10}{*}{ 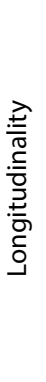 } & Blood pressure measurement & 13.3 & 64.6 & 22 \\
\hline & $\begin{array}{l}\text { Scheduling appointments and medical and nursing } \\
\text { return visits }\end{array}$ & 17.4 & 59.0 & 23.4 \\
\hline & Nursing entry on medical records & 10.6 & 76.0 & 13.3 \\
\hline & Cappilary blood glucose (CBG) testing & 8.0 & 54.6 & 37.2 \\
\hline & Education-in-health-inside-and-outside the-unit & 44 & 10.6 & 45.3 \\
\hline & Participation in vaccination campaigns & 22.8 & 5.3 & 71.8 \\
\hline & Participation in team meetings & 14.6 & 3.3 & 81.9 \\
\hline & $\begin{array}{l}\text { Planning and execution of activities with the health } \\
\text { team }\end{array}$ & 17.3 & 19.3 & 63.2 \\
\hline & Make a dressing & 18.6 & 32.0 & 49.3 \\
\hline & Home visit & 38.9 & 0 & 60.9 \\
\hline \multirow{4}{*}{ 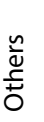 } & Production record & 22.0 & 69.3 & 8.5 \\
\hline & Checking and replacement of supplies & 13.4 & 29.5 & 56.9 \\
\hline & Checking and replacement of emergency supplies & 45.3 & 8.0 & 46.6 \\
\hline & Request for nursing supplies & 22.6 & 10.0 & 67.3 \\
\hline
\end{tabular}

Note:IV-Intravenous; IM - Intramuscular; SL - Sublingual;SC - Subcutaneously;ID-Intradermal, SINAN - Notifiable Diseases Information System.

Among the nursing categories analyzed, there is a transition evident in the profession called "rejuvenation"(10), since the average age was 48.39 years for the auxiliary nurses and 37.80 years for the nurse technicians. This change movement initiated when the auxiliary nurses, who were in the third phase of professional life, entered into the retirement process. From 2011, there was a new position, nurse technician, through a public tender, so the professional staff is in transition.

Data from the Federal Nursing Council make it possible to verify the tremendous numerical expressiveness of nursing in Brazil: 
in June 2020, it was represented by 2,322,327 professionals, of which 420.588 were auxiliary nurses, 1,333,160 nurse technicians, 568,281 registered nurses, and 298 obstetric nurses ${ }^{(6)}$. Although the absolute number of nurse technicians in Brazil is approximately three times that of auxiliary nurses, this proportion was not observed in FHS teams' composition. A study conducted in the state of Ceará on the sociodemographic profile of FHS auxiliary nurses and nurse technicians revealed that $69 \%$ of the professionals belonged to the category of auxiliary nurses ${ }^{(11)}$.

A large number of auxiliary nurses at FHS is justified by the professional training initiatives of the Ministry of Health (MS) in partnership with the Ministry of Education (MEC), in order to train nursing attendants who were working at SUS, such as the "Large Scale Project" (PLE) ${ }^{(12)}$. In 1981, the "Large Scale Project" (PLE) acted at the national level to solve the lack of qualification and increase the number of nursing professionals, professionalizing this category through training in regular service auxiliary nurse and/or nurse technician or by proof of professional replacement, providing scientific background for nursing care ${ }^{(12-13)}$.

With the advance of the time of experience in $\mathrm{PHC}$, these professionals gave continuity in their formative process, raising the schooling to the technical level and/or bachelor in nursing; however, they remained acting in the same function. In a study carried out in Brazil, it was identified that $57.7 \%$ of these professionals were already graduated in high school, and $34.7 \%$ were already in higher education or were already bachelors ${ }^{(14)}$. Such fact suggests an interest in professional ascension, however without the actual possibility of occupying vacancy in the category corresponding to the new level of acquired formation: for the scarcity of new vacancies of superior level, the alteration of the position does not occur, and the real impact in the practices of the qualification of the auxiliary nurses and nurse technicians in nursing is unknown.

Regarding professional updating, the interviewees, when reporting their participation in events promoted by their own institution, referred to the concept of continuing education, in which educational processes are based on pedagogical strategies of knowledge accumulation and directives, on a non-routine basis and with specific themes for the professional category ${ }^{(15)}$. However, it is worth reinforcing the importance of continuing education incorporated into the PHC teams' work process, aiming at transforming the local reality of professional practices and the work organization in the scenarios where it is implemented with all its potential ${ }^{(16)}$.

Social participation was incipient among the study participants. Nursing cannot be reduced only to technical-scientific competence but also recognized as social practice, having these interfaces with economic, cultural, ethical, and social aspects that, together with other professionals, participate in the construction of health practices. In the face of this, it composes historical changes, determining its insertion in the collective and social movements ${ }^{(17)}$.

The low political participation identified also leads to the reflection that their disarticulation, both social and professional, shows professionals who, despite representing the largest contingent of health workers, remain subordinated and alienated in the context in which they are inserted ${ }^{(17)}$.

The consolidation of the SUS and advancement of public policies aimed at caring for the individual and the community in an integrated manner have contributed to the expansion and strengthening of the nursing labor market. Given its central role in the PHC consolidation, mostly due to the creative, versatile, and innovative potential of health promotion professionals, prevention of diseases and illnesses, and provision of care ${ }^{(17-18)}$.

The history of nursing originated with much responsibility in the direct assistance to the patients and accomplishing the tasks according to the experiences acquired during the service time, without a specific formation in care, represented by the category of the nursing attendants. The increase of population demands and the complexity of health services required new ways for caring that offered integrated assistance to the population, qualifying this nursing workforce ${ }^{(13)}$.

Historically, Brazilian nursing started with the nursing attendants, who, in the context of PHC, were called "public health auxiliary nurses"(19). Currently, the two existing professions, auxiliary nurses and nurse technicians, are in a transition.

Each professional category has its training process, which presupposes a distinct set of regulated activities by the Law of Professional Exercise of Nursing, Law № 7.498/86 (20). Art. 12 refers to the Nurse Technicians' professional exercise and Art. 13 to the Auxiliary Nurses. It should be emphasized that the registered nurses are responsible for the supervision of these professionals, according to art. $15^{(20)}$.

Even with the changes that have occurred in recent decades, it is difficult to observe these professional divisions in HCCs, i.e., nurse technicians and auxiliary nurses perform the same activities. That happens for different reasons: among them, the historical and social construction of nursing work at PHC and the excessive load of activities in the daily life of each worker, corroborated by the limited scientific production on the subject.

At PHC, nursing professionals continuously stand out, whether in the implementation, expansion, organization of services and care to the SUS population, demonstrating their work as fundamental and building its practices ${ }^{(21-22)}$.

$\mathrm{PHC}$ services are recognized as the gateway to the health system, as they are structured close to people, guaranteeing accessible care when populations need $i^{(7)}$. In Brazil, they have been structured and constituted as a range of services to populations, developed by multi-professional health teams, in which auxiliary nurses and nurse technicians are included.

Among the activities carried out by auxiliary nurses and nurse technicians, the users' orientation stood out as the most common, since nursing professionals are in daily contact with users, representing the largest contingent of professionals present in the Health Basic Units. Thus, auxiliary nurses and nurse technicians are the professionals that have more contact with the public or even the "First contact" at PHC.

Another activity performed daily by auxiliary nurses and nurse technicians was the "Intake," an ethical posture, which implies both listening to the user about their complaints and understanding of their protagonism in the process of health and illness. According to the Ministry of Health's Ordinance № 2.436, of September 21, 2017, the hosting activity is a common attribution of all FHS team members ${ }^{(1)}$. However, in the municipality studied, since the implementation of FHS, it has been an activity essentially developed by the nursing team, auxiliary nurses, and 
nurse technicians with the supervision of registered nurses, with support from the medical team.

In 2004, an investigation about auxiliary nurses' practices at FHS demonstrated that these professionals helped to attend the spontaneous demand, in the screening of patients, to repress and control the demand brought by users. These services were fast, based on complaint and conduct, without creating a link with health services ${ }^{(23)}$. In turn, a review study of 2015 found that these professionals were the most prepared to perform such practice ${ }^{(24)}$. Therefore, "Intake" has been changing over the years, enabling the development of listening, accountability, resoluteness, and autonomy promotion capabilities ${ }^{(24)}$. In this sense, the "Intake" performed by auxiliary nurses and nurse technicians is of extreme importance for the organization of the unit work process.

The activities referred to by these professionals provide access to the SUS and contribute to facilitating the flow of users through the service, whether for guidance, organization, or even qualified to listen. The most frequent activities mentioned indicate the power of these professionals' work, their insertion in several fronts, and the permeability of their performance in the context of PHC.

The auxiliary nurses and nurse technicians point out that they are the most sought after professionals in the health services for their performance in several activities, which characterizes their work as relevant and essential for the consolidation of PHC. Simultaneously, their insertion, capillarity of performance, and work time indicate a permanent relationship with the users.

Another attribute highlighted in this study was "Longitudinality," which is primordial in the context of PHC since it reflects the lasting relationship between professionals and users ${ }^{(7)}$. The activities performed daily by auxiliary nurses and nurse technicians characterize the potential of longitudinal care, unique to the FHS, such as the home visit.

It is important to emphasize that the nursing entry in the patient's chart is fundamental in nursing care. It consists of an essential instrument of evaluation of the nursing performance quality because it documents activities, occurrences, and intercurrences during the execution of procedures. However, despite $76 \%$ of the medium-level nursing professionals declaring to write down in the user's register, $22 \%$ did not register the activities in the production spreadsheet. Therefore, without this register, the diverse activities that the auxiliary nurses and nurse technicians complete during their workday are not documented, not having legal recognition of how much they produce and how much is the volume of work. This situation can be modified if auxiliary nurses and nurse technicians start to make entries and record their production.

\section{Study limitations}

The study's main limitation was the sample size not comparable between the two categories due to the difficulties in data collection. Another point was the limited literature on auxiliary nurses and nurse technicians in the context of $\mathrm{PHC}$, including the different realities of the countries. There are significant productions only about nurses, excluding the other categories. Even the recent production of the World Health Organization (2020) on nursing corroborates this fact by excluding the auxiliary nurses ${ }^{(25)}$.

\section{Contributions to the fields of Nursing, Health or Public Policy}

The insertion of auxiliary nurses and nurse technicians demonstrates the capillarity of their practices in Health Basic Units, for being present in all sectors of these services, evidencing the importance of their labor force at FHS. Professionals with a profile to act in a differentiated way to accomplish a change in the assistance model need to be empowered by training and work. One of the challenges for nursing at $\mathrm{PHC}$ is the qualification and training of nursing professionals with autonomy and respect for their work and the users.

\section{CONCLUSIONS}

The social profile of the auxiliary nurses and nurse technicians presents itself as a job executed by women. The developed practices evidenced potentialize the essential attributes in the PHC of the "First contact" and "Longitudinality," corroborating the relevance of these professionals' work in the consolidation of the FHS at PHC.

The group of activities demonstrates the insertion and capillarity of these professionals' work, characterizing their authorship in the social and historical construction of SUS.

\section{FUNDING}

Conselho Nacional de Desenvolvimento Científico e Tecnológico (CNPq) e Fundo de Apoio ao Ensino, Pesquisa e Extensão (FAEPEX).

\section{REFERENCES}

1. Ministério da Saúde (BR). Portaria $n^{\circ}$ 2.436, de 21 de setembro de 2017. Aprova a Política Nacional de Atenção Básica, estabelecendo a revisão de diretrizes para a organização da Atenção Básica, no âmbito do Sistema Único de Saúde (SUS) [Internet]. Brasília: Ministério da Saúde; 2017 [cited 2020 Aug 27]. Available from: https://bvsms.saude.gov.br/bvs/saudelegis/gm/2017/prt2436_22_09_2017.html

2. Ferreira SRS, Périco LAD, Dias VRGF. The complexity of the work of nurses in Primary Health Care. Rev Bras Enferm. $2018 ; 71($ Supl-1):704-9. https://doi.org/10.1590/0034-7167-2017-0471

3. Santos DS, Mishima SM, Merhy EE. Processo de trabalho na Estratégia de Saúde da Família: potencialidades da subjetividade do cuidado para reconfiguração do modelo de atenção. Ciênc Saúde Coletiva. 2018;23(3):861-70. https://doi.org/10.1590/1413-81232018233.03102016

4. Moraes LMS, Rabelo DBM, Áfio JX, Lavinas CMS, Santos DMA. The use of soft-hard technology in nursing practice: concept analysis. Aquichan. 2016;16(2):230-9. https://doi.org/10.5294/aqui.2016.16.2.10 
5. Toassi RFC, Lewgoy AMB. Integrated health practices I: an innovative experience through inter-curricular integration and interdisciplinarity. Interface Comun Saúde Educ. 2016;20(57):449-61. https://doi.org/10.1590/1807-57622015.0123

6. Conselho Federal de Enfermagem (COFEN). Enfermagem em números [Internet]. Brasília: COFEN; 2020 [cited 2020 Aug 27]. Available from: http://www.cofen.gov.br/enfermagem-em-numeros

7. Starfield B. Atenção Primária: equilíbrio entre as necessidades de saúde, serviços e tecnologias. Brasília: UNESCO, Ministério da Saúde; 2002. $726 \mathrm{p}$.

8. Instituto Brasileiro de Geografia e Estatística (IBGE). Estimativas da população em 2018 [Internet]. Brasília: IBGE, 2020 [cited 2020 Aug 27$].$ Available from: https://www.ibge.gov.br/estatisticas/sociais/populacao/9103-estimativas-de-populacao.html?edicao=17283\&t=downloads

9. Pagano M, Gauvreau K. Princípios de Bioestatística. São Paulo: Pioneira Thomson Learning, 2004.

10. Machado MH, Aguiar Filho W, Lacerda WF, Oliveira E, Lemos E, Wermelinger M, et al. Características gerais da enfermagem: o perfil sóciodemográfico. Rev Enf Foco. 2016;7(Esp.):9-14. https://doi.org/10.21675/2357-707X.2016.v7.nESP

11. Ximenes Neto FRG, Costa MCF, Rocha J, Cunha ISKO. Nursing assistants and technicians in the family health: sociodemographic profile and qualification needs. Trab Educ Saúde. 2008;6(1):51-64. https://doi.org/10.1590/S1981-77462008000100004

12. Bassinello GAH, Bagnato MHS. Os primórdios do projeto larga escala: tempo de rememorar. Rev Bras Enferm. 2009;62(4):620-26. https://doi. org/10.1590/S0034-71672009000400022

13. Reis RS, Muniz LB, Chagas DC, Pinho JRO, Fernandes ACUR, Duarte KMM, et al. Desafios da formação de trabalhadores de nível médio para o Sistema Único de Saúde no Maranhão. Trab Educ Saúde. 2020;18(2):e0025991. https://doi.org/10.1590/1981-7746-sol00259

14. Machado $M H$, Wermelinger $M$, Vieira M, Oliveira $E$, Lemos W, Aguiar Filho W, et al. Aspectos gerais da formação da enfermagem: o perfil da formação dos enfermeiros, técnicos e auxiliares. Enferm Foco. 2016;7(esp): 15-34. https://doi.org/10.21675/2357-707X.2016.v7.nESP.687

15. Ferreira L, Barbosa JSA, Esposti CDD, Cruz MM. Permanent Health Education in primary care: an integrative review of literature. Saúde Debate. 2019;43(120):223-39. https://doi.org/10.1590/0103-1104201912017

16. Pinheiro GEW, Azambuja MS, Bonamigo AW. Facilities and difficulties experienced in Permanent Health Education, in the Family Health Strategy. Saúde Debate. 2018;42(esp 4):187-197. https://doi.org/10.1590/0103-11042018s415

17. Lessa ABSL, Araújo CNV. Brazilian nursing: a reflection about political activity. Rev Min Enferm. 2013;17(2):474-81. https://doi. org/10.5935/1415-2762.20130036

18. Thumé E, Fehn FC, Acioli S, Fassa MEG. Formação e prática de enfermeiros para a Atenção Primária à Saúde: avanços, desafios e estratégias para fortalecimento do Sistema Único de Saúde. Saúde Debate. 2018;42(esp-1): 275-88. https://doi.org/10.1590/0103-11042018S118

19. Nascimento EPL, Nozawa MR. O trabalho das enfermeiras no SUS de Campinas: anos 70 e 80. Rev Bras Enferm. 2004;57(2):212-6. https://doi. org/10.1590/S0034-71672004000200016

20. Ministério do Trabalho (BR). Lei no 7498 de 25 de junho de 1986. Dispõe sobre a regulamentação do exercício da enfermagem[Internet]. Brasília: Ministério do Trabalho; 1986 [cited 2020 Nov 30]. Available from: http://www.planalto.gov.br/ccivil_03/LEIS/L7498.htm

21. Ribeiro HA, Rennó HMS, Gontijo TL, Cavalcante RB. Processo de trabalho do profissional de nível médio de enfermagem na Estratégia Saúde da Família. Rev Enferm Cent O Min. 2016;6(3):2307-17. https://doi.org/10.19175/recom.v6i3.985

22. Ogata MN, França Y. Nursing assistant performance in the Family Health strategy. Acta Paul Enferm. 2010;23(4):506-11. https://doi. org/10.1590/S0103-21002010000400010

23. Shimizu HE, Dytz JLG, Lima MG, Moura AS. The practice of nursing auxiliaries in the family health program. Rev Latino-Am Enfermagem. 2004;12(5):713-20. https://doi.org/10.1590/S0104-11692004000500003

24. Coutinho LRP, Barbieri AR, Santos MLM. Acolhimento na Atenção Primária à Saúde: revisão integrativa. Saúde Debate. 2015;39(105):514-24. https://doi.org/10.1590/0103-110420151050002018

25. World Health Organization (WHO). State of the world's nursing 2020: investing in education, jobs and leadership. Geneva: World Health Organization; 2020. 116p. 